\title{
Cytotoxic effect and apoptotic activity of Parmentiera edulis DC. hexane extract on the breast cancer cell line MDA-MB-231
}

\author{
Cynthia Carolina Estanislao Gómez ${ }^{\mathrm{a}^{*}}$, Cynthia Ordaz Pichardo ${ }^{\mathrm{a}}$, Eduardo San Martín Martínez ${ }^{\mathrm{b}}$, Nury Pérez Hernández ${ }^{\mathrm{a}}$, \\ Guillermo Pérez Ishiwara ${ }^{\mathrm{a}, \mathrm{c}}$, María del Consuelo Gómez García ${ }^{\mathrm{a}}$ \\ ${ }^{a}$ Programa de Biomedicina Molecular, Escuela Nacional de Medicina y Homeopatía, Instituto Politécnico Nacional, México, D.F., ${ }^{b}$ Centro de Investigación \\ en Ciencia Aplicada y Tecnología Avanzada, Unidad Legaria Instituto Politécnico Nacional. México D.F., 'Centro de Investigación en Biotecnología \\ Aplicada, Instituto Politécnico Nacional, Tlaxcala, México.
}

\begin{tabular}{l} 
ARTICLE INFO \\
\hline Article history: \\
Received on: $11 / 09 / 2015$ \\
Revised on: $28 / 10 / 2015$ \\
Accepted on: $15 / 11 / 2015$ \\
Available online: $26 / 01 / 2016$ \\
\hline Key words: \\
Cancer; Parmentiera edulis; \\
MDA-MB-231; apoptosis; \\
caspases.
\end{tabular}

\begin{abstract}
Parmentiera edulis is a traditional medicine plant used for different purposes in Mexico; however its biological effects and their potential mechanisms have not been sufficiently investigated. In the present work, the in vitro cytotoxic and pro-apoptotic potential effects of hexane extract of bark of $P$. edulis on the MDA-MB-231 breast cancer cell line were studied. The hexane extract elicited the most pronounced cytotoxic effect in breast cancer cells, as evaluated by MTT assays performed $72 \mathrm{~h}$ after treatment, showing an $\mathrm{IC}_{50}$ value of $94.63 \pm 1.63 \mu \mathrm{g} / \mathrm{ml}$. No effects were observed in the immortalized mammary epithelial MCF10A cell line and lymphocytes. The antiproliferative activity observed following $P$. edulis treatment was associated with morphological changes, DNA fragmentation, phosphatidyl serine externalization and activation of caspases 3 and 9 , all of them typical characteristics of apoptosis. Our findings demonstrate specific cytotoxic activity of $P$. edulis and the apoptosis induction through the intrinsic pathway in the breast cancer cells. Further research is necessary to find out the effective secondary metabolites responsible of cell death induction.
\end{abstract}

\section{INTRODUCTION}

The worldwide use of natural products including medicinal plants has become increasingly important in primary health care. Natural products are excellent alternatives for therapeutics, particularly in developing countries, because of their relatively well-established safety profile (Graham et al., 2000; Da Rocha et al., 2001; Moura and Silva, 2002; Cragg and Newman 2005a,b). Phytochemicals isolated from herbs have emerged as a new and promising source of anticancer remedies, or as adjuvants for chemotherapeutic drugs, to enhance their efficacy and decrease side effects (De Vita et al., 2001; Balunas and Kinghorn, 2005; Newman and Cragg, 2007; Newman, 2008; Bailly, 2009). Cancer is responsible for approximately $25 \%$ of deaths in developed countries and $15 \%$ of all deaths worldwide (Ferlay et al., 2013). Specifically, breast cancer is the leading cause of cancer-related death in women

\footnotetext{
* Corresponding Author

Laboratorio de Biomedicina Molecular I. Escuela Nacional de Medicina y Homeopatía, Instituto Politécnico Nacional. Guillermo Massieu Helguera No. 239, Fracc. La Escalera, Ticomán, C.P. 07320, México, D.F. Tel.: (+46)57296000 ext 55541; Fax: (+46) 57296000 ext 55534.E-mail: cgomezg@ipn.mx
}

worldwide suggesting that further improvement in therapy is needed because the treatments are currently based on a combination of surgery, radiation, hormonal therapy and chemotherapy.

However, to date, there have been no completely successful intervention options developed as such, new treatments derived from traditional medicine, medicinal chemistry and rational drug design are necessary. Mexico is a country with extensive flora diversity, and the traditional use of various medicinal plants is common across the country (Laza et al., 2003).

Many people use medicinal plants to treat different diseases, including infections, cancer and multiple types of inflammation. Parmentiera edulis DC is a medicinal tree from Mexico that grows up to 5 meters tall and belongs to the Bignoniaceae family.

It grows at an altitude range of $2-2240$ meters above sea level in the northern central mountain region of Tamaulipas and is commonly called "cuajilote" (Pennington and Sarukan, 2005; Perez et al., 1998; Rzedowsky and Rzedowsky, 2001). People in the local community use an infusion of fruits but other parts of the plant as the bark are also used to treat diabetes, gastroenteritis, flu, cough and fever in addition to breast cancer (Perez et al., 1998, Hernandez-Galicia et al., 2002; Perez et al., 2000; Sorela 2006). 
To date only the hypoglycemic activity of $P$. edulis fruit has been reported (Perez et al., 2000). Therefore, the medicinal properties of this plant against other diseases as cancer have been no studied. Therefore, the main aim of this study was to evaluate the cytotoxic effect of different extracts of $P$. edulis on breast carcinoma cells (MDA-MB-231 cell line) and determine the mechanisms by which they induce cell death. Our findings revealed that the hexane extract inhibited the growth of MDAMB-231 cells but did not affect the MCF10A epithelial breast cells or lymphocyte primary culture. The immunochemical analysis showed that this extract induced apoptosis via the mitochondrial intrinsic pathway. These combined observations suggest that the hexane extract from $P$. edulis shows potential anti-cancer activity in breast cancer cells.

\section{MATERIAL AND METHODS}

\section{Plant material}

$P$. edulis stem bark was collected from Gomez Farias, Tamaulipas in the spring of 2009. The plant was identified as $P$. edulis D. C. by Maria Patricia Jacquez Rios of the Facultad de Estudios Superiores Iztacala (FESIzta), UNAM, Mexico. A representative specimen (number 1766) is available at the institute's Izta Herbarium.

\section{Preparation of $\boldsymbol{P}$. edulis extracts}

The bark of $P$. edulis was cut into small pieces, and $25 \mathrm{~g}$ were extracted with $250 \mathrm{ml}$ of water, acetone or hexane for $96 \mathrm{~h}$ at room temperature. Subsequently, each extract was filtered and concentrated using a rotary evaporator under vacuum conditions to obtain a final residue. The yield of the dried residue for the water, acetonic and hexane extract was 25, 2 and 9 percent, respectively. Each extract was dissolved in $0.1 \%$ DMSO and diluted with DMEM (Dulbecco's Modified Eagle Medium, Gibco) media to the desired final concentration. Stock solutions were stored at $-20^{\circ} \mathrm{C}$. The $P$. edulis extracts used for experimentation ranged in concentration from 25 to $350 \mu \mathrm{g} / \mathrm{ml}$.

\section{Phytochemical screening of the extracts of $\boldsymbol{P}$. edulis}

The chemical constituents in the different extracts were screened using chemical protocols and methodologies, as previously described (Shrivastava et al., 2013). Plant extracts were screened for the presence of sugars, carbohydrates, glycosides, flavonoids, tannins, coumarins, alkaloids, steroids, saponins, sesquiterpenes and quinones.

\section{Cell culture}

MDA-MB-231, a breast adenocarcinoma cell line, was cultured in DMEM, supplemented with 5\% fetal bovine serum (Invitrogen). MCF10A, an epithelial mammary cell line, was cultured in DMEM-F12 supplemented with $10 \%$ fetal bovine serum, $100 \mathrm{mg} / \mathrm{ml} \mathrm{EGF,} 100 \mathrm{mg} / \mathrm{ml}$ insulin and $1 \mathrm{mg} / \mathrm{ml}$ hydrocortisone. Cells were maintained in $75 \mathrm{~cm}^{2}$ flasks in a humidified incubator at $37^{\circ} \mathrm{C}$ with $5 \% \mathrm{CO}_{2}$ (Debnath et al., 2003).
Furthermore, human peripheral blood lymphocytes were isolated and cultured as described previously (Hofman et al., 1982). Briefly, after diluting blood with PBS, the lymphocytes were isolated by centrifugation over a lymphocyte-specific density gradient using a Hystopaque-1077 solution (Sigma) for $30 \mathrm{~min}$ at $400 \mathrm{~g}$ at room temperature. The layer containing mononuclear cells was then aspirated, and isolated cells were washed twice with PBS. The cells were suspended in complete RPMI media (Invitrogen) with $10 \%$ fetal bovine serum.

\section{Cytotoxicity assay: 3-(4, 5-dimethylthiazol-2-yl)-2,5-diphenyl tetrazolium bromide (MTT) assay}

The cytotoxicity effects of the different extracts on MDA-MB-231, MCF10A and lymphocytes were determined using an MTT assay as previously described (Youn et al; 2009). Briefly, the cells were plated (7000 cells/well) onto a 96-well plate. Following a $24 \mathrm{~h}$ incubation and attachment, the plating medium was removed and replaced with fresh medium with or without extract treatment. The cells were treated with media alone, or different concentrations $(25-1000 \mu \mathrm{g} / \mathrm{ml})$ of aqueous, acetonic or hexane plant extracts for 24,48 and $72 \mathrm{~h}$ at $37^{\circ} \mathrm{C}$. Paclitaxel $(0.25$ $\mu \mathrm{g} / \mathrm{ml})$ was used as a positive control. After incubation, $20 \mu \mathrm{l}$ of MTT solution $(5 \mathrm{mg} / \mathrm{ml})$ was added to each well, and the plates were incubated at $37^{\circ} \mathrm{C}$ for $4 \mathrm{~h}$. Subsequently, the supernatant was removed and $100 \mu \mathrm{l}$ of DMSO were added to each well to solubilize the formazan crystals. Absorbance was quantified at $570 \mathrm{~nm}$ using an ELISA reader (Labsystem Multiskan Ms). Experiments were performed in triplicate. The results are expressed as the percentage of cell proliferation with respect to the media-treated cells. GraphPad Prism 5.0 software was used to calculate the $\mathrm{IC}_{50}$ values (Loyola and Vazquez, 2006). Also, selective index (SI) value was calculated as the ratio of $\mathrm{IC}_{50}$ of cancer cells to the $\mathrm{IC}_{50}$ of normal cells.

\section{Cell Morphology Analysis}

Cells were stained with hematoxylin and eosin to qualitatively analyze their morphological characteristics (Stander et al., 2009). MDA-MB-231 cells $\left(1 \times 10^{4}\right)$ were seeded on 6-well plates. After $24 \mathrm{~h}$ of incubation, the medium was removed and the cells were treated with hexane extract $(94.63 \pm 1.63 \mu \mathrm{g} / \mathrm{ml})$, Paclitaxel $(0.25 \mu \mathrm{g} / \mathrm{ml})$ or media alone for $6,12,24,48$ and $72 \mathrm{~h}$. After incubation, the cells were washed in PBS and fixed using a $4 \%$ paraformaldehyde solution. The cells were then stained with hematoxylin and eosin and analyzed under a light microscope (Nikon Eclipse TE300).

\section{Annexin V-FITC binding assay}

Apoptotic cells were detected using an Annexin V-FITC Apoptosis Detection Kit (Biovision) following the manufacturer's instructions. Briefly, MDA-MB-231 cells $\left(1 \times 10^{7}\right)$ were seeded and allowed to proliferate for $24 \mathrm{~h}$. The medium was then removed and cells were treated with medium alone, Paclitaxel $(0.25 \mu \mathrm{g} / \mathrm{ml})$ or hexane extract $(94.63 \pm 1.63 \mu \mathrm{g} / \mathrm{ml})$. After $6,12,24$ and $48 \mathrm{~h}$ of treatment, cells were harvested by trypsinization, centrifuged, 
washed in PBS and re-suspended in binding buffer. Subsequently, $5 \mu 1$ of Annexin V-FITC and $5 \mu 1$ of propidium iodide were added, and the samples were incubated at room temperature for $5 \mathrm{~min}$. Cells were then analyzed using flow cytometry (FACScan, Beckton Dickinson Cytometer).

\section{Terminal dUTP nick end labeling (TUNEL)}

A TUNEL assay was also used to detect apoptosis by analyzing DNA fragmentation with the In Situ Cell Death Detection Kit AP (Roche) according to the manufacturer's instructions. Briefly, MDA-MB-231 cells $\left(1 \times 10^{5}\right)$ were cultured on cover slips for $24 \mathrm{~h}$; after incubation, the cells were treated with hexane extract $(94.63 \pm 1.63 \mu \mathrm{g} / \mathrm{ml})$, Paclitaxel $(0.25 \mu \mathrm{g} / \mathrm{ml})$ or media alone for $6,12,24$ and $48 \mathrm{~h}$. The cells were washed with PBS, fixed with $4 \%$ paraformaldehyde solution, and immersed in permeabilization solution $(0.1 \%$ Triton $\mathrm{X}-100$ in $0.1 \%$ sodium citrate) for $30 \mathrm{~min}$ at $4^{\circ} \mathrm{C}$ and washed with PBS. The cells were then incubated in kit's solutions $\mathrm{A}$ and $\mathrm{B}$ for $60 \mathrm{~min}$ at $37^{\circ} \mathrm{C}$ in the dark and finally washed in PBS and examined under a fluorescence microscope (Nikon diaphot 200) supported with a laser scanning confocal imaging system (MCRR 1024).

\section{Western blotting analysis}

MDA-MB-231 cells were cultured $\left(1 \times 10^{7}\right)$ for $24 \mathrm{~h}$. After incubation, the cells were treated with medium alone, Paclitaxel $(0.25 \mu \mathrm{g} / \mathrm{ml})$ or hexane extract for $6,12,24,48$ and $72 \mathrm{~h}$. The cells were then washed with PBS, harvested by trypsinization, centrifuged, and the pellet was re-suspended in ice-cold lysis buffer $(50 \mathrm{mM} / \mathrm{L}$ Tris-HCl, $150 \mathrm{mM} / \mathrm{L} \mathrm{NaCl}, 0.1 \%$ SDS, $1 \%$ NP$40,0.5 \%$ sodium deoxycholate, $1 \mathrm{mmol} / \mathrm{L}$ phenylmethylsulfonyl fluoride, $100 \mu \mathrm{g} / \mathrm{L}$ leupeptin, and $2 \mu \mathrm{g} / \mathrm{L}$ aprotinin) containing a protease inhibitor cocktail.

The protein lysates were centrifuged at 13,300 rpm for 5 min at $4{ }^{\circ} \mathrm{C}$ to remove insoluble material and the protein concentration in the supernatants was determined using the Bradford protein quantification assay. Protein lysates were subjected to electrophoresis on 15\% SDS-polyacrylamide gels and transferred to $0.45 \mu \mathrm{m}$ nitrocellulose membranes. The membranes were stained with $0.2 \%$ Ponceau $\mathrm{S}$ red to ensure equal protein loading and transfer. After blocking the membranes with 5\% milk in PBS-Tween, they were incubated with primary rabbit polyclonal antibodies targeting procaspase -3 (1:200, Santa Cruz, CA), procaspase-8 (1:200, Santa Cruz, CA), procaspase-9 (1:200, Santa Cruz, CA) or $\beta$-actin (1:2000, Santa Cruz, CA) as a positive control overnight at $4^{\circ} \mathrm{C}$. The membranes were then incubated with horseradish peroxidase-conjugated secondary antibody (1:2000), and the immunocomplexes were visualized by ECL western blotting detection reagents. All experiments were performed in triplicate.

\section{Statistical analysis}

All data are expressed as the means \pm S.E. One-way ANOVA followed by Tukey's tests were used to compare all groups to each other. For all tests, $\mathrm{p}<0.05$ was considered significant.

\section{RESULTS AND DISCUSSION}

The development of new therapeutic strategies, such as integrative and complementary medicine, for breast cancer treatment is greatly needed. Medicinal plants are very important in folk and traditional medicine across many countries. Specifically in Mexico, plants have been utilized in traditional medicine since pre-Hispanic times (Alonso-Castro et al., 2011; Waizel, 2012). P. edulis is a plant that has been used to treat cancer in the different communities of Tamaulipas, Mexico. However, the bioactivity of $P$. edulis extracts has not been established. Thus, we investigated the cytotoxic activity of different $P$. edulis extracts against breast cancer cells by assessing both cellular and molecular changes.

\section{Effects of $P$. edulis hexane extract on the MDA-MB-231 breast cancer cell line}

The cytotoxicity activity of $P$. edulis extracts against MDA-MB-231 breast carcinoma cells was evaluated using MTT assays. To this end, the metastatic cell line MDA-MB-231 was cultured with medium alone, DMSO $0.2 \%$ (negative control), Paclitaxel $(0.25 \mu \mathrm{g} / \mathrm{ml}$; positive control) or aqueous, acetonic or hexane plant extracts at different concentrations $(25-350 \mu \mathrm{g} / \mathrm{ml})$ for 24,48 and $72 \mathrm{~h}$.

The viability of negative control cells was considered the $100 \%$ mark, whereas the viability of cells exposed to the positive control, Paclitaxel, decreased by $35.25 \%$ after $72 \mathrm{~h}$ of treatment. The aqueous extract did not show any cytotoxic activity at any presenting concentration or at any time, while the acetonic extract inhibited only $26 \%$ of cell proliferation after $72 \mathrm{~h}$ of incubation (data not shown). In contrast, cytotoxic effect was most pronounced when cells were treated with the hexane extract (Fig. 1). The viability of cancer cells treated with 25 or $50 \mu \mathrm{g} / \mathrm{ml}$ of hexane extract for $72 \mathrm{~h}$ was reduced by $19.55 \%$ and $25.95 \%$, respectively. Moreover, the decreases in viability were reduced by $94.2 \%$ when treated with the highest concentration, $350 \mu \mathrm{g} / \mathrm{ml}$, of extract after $72 \mathrm{~h}$. Therefore, the hexane extract showed both a time and dose-dependent inhibition of MDA-MB-231 cell proliferation. The $\mathrm{IC}_{50}$ value obtained for hexane extract was 94.63 $\pm 1.63 \mu \mathrm{g} / \mathrm{ml}$.

Because the hexane extract showed the most pronounced effect in initial experiments, additional cell types, such as a primary lymphocyte culture and the normal MCF10A epithelial mammary cell line, were treated with different concentrations of the hexane extract $(25-1000 \mu \mathrm{g} / \mathrm{ml})$ for varying durations $(24,48$ and $72 \mathrm{~h}$ ) to ensure that the effect of the hexane extract was specific to cancer cells. Interestingly, both cell lines were significantly less sensitive to $P$. edulis extract, showing $\mathrm{IC}_{50}$ values of $926.8 \pm 2.8$ (MCF10A) and $864.5 \pm 2.9 \mu \mathrm{g} / \mathrm{ml}$ (lymphocyte culture) (data not shown). On the other hand, the selective index value of hexane extract against MDA-MB-231 and MCF10A cells was 0.10 


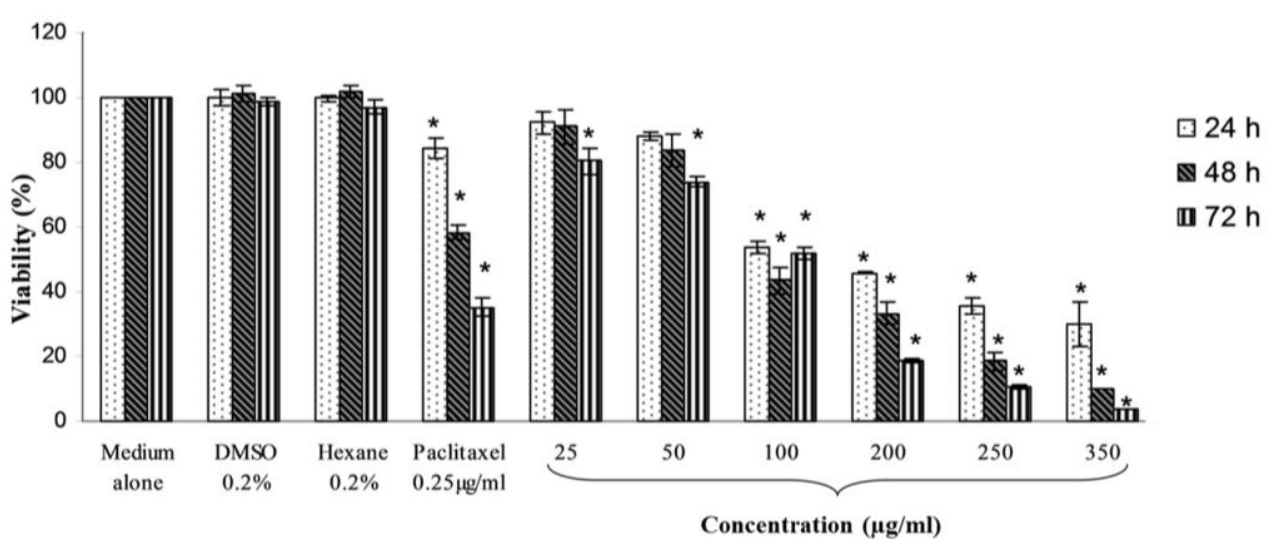

Fig. 1: Cytotoxic effect of $P$. edulis hexane extract on the breast cancer cell line MDA-MB-231. Cells were treated with medium alone, $0.2 \%$ DMSO or $0.2 \%$ hexane as negative controls and with Paclitaxel as a positive control. Cells were also treated with various concentrations of the hexane plant extract for 24,48 and $72 \mathrm{~h}$. Experiments were performed in triplicate and the values are reported as the mean $\pm \mathrm{SE}, * \mathrm{P}<0.05$ compared to control cells (medium alone). Significance was assessed using a one-way ANOVA followed by Tukey's test.

This finding indicated that normal cells were less sensitive to the cytotoxicity of $P$. edulis hexane extract, probably due to membrane or cytoskeleton proteins, genetic changes, motility or cell surface differences between cancer and normal cells (Agus et al., 2013). These results indicated that the cytotoxic components present in the hexane extract of $P$. edulis showed a selective and specific cytotoxic action against tumor cells. Based on these results, the hexane extract was chosen for further investigation in subsequent experiments.

\section{Morphological analyses of MDA-MB-231 cells treated with hexane extract}

To investigate if the cytotoxicity induced by the $P$. edulis hexane extract was produced by a specific apoptosis or necrosis process, the cells were exposed to hexane extract and were, then stained with H\&E and analyzed under a light microscope. Untreated cells appeared to be elongated, forming a confluent colony and attaching to the plate (Fig. 2A). In contrast, important changes in the morphology and density of cells were observed after treatment with $94.63 \mu \mathrm{g} / \mathrm{ml}$ of hexane extract for $6,12,24$ and $48 \mathrm{~h}$ (Fig. 2C-F). After $6 \mathrm{~h}$ of treatment, changes, such as cell size reduction and loss of colony formation were observed. These cellular changes increased over time, and other morphological characteristic changes of apoptosis, such as chromatin condensation and the formation of apoptotic bodies, were also observed (Fig. 2D-F). After $48 \mathrm{~h}$ of treatment, the cells appeared rounded and detached, with clear membrane blebbing and presence of apoptotic bodies. Similar morphological characteristics were observed in the cells exposed to Paclitaxel, in which the apoptotic process has been previously described (Fig. 2B) (Ofir et al., 2002).

\section{Cell death analyses by Annexin V-FITC binding assay}

To confirm and quantify apoptosis, MDA-MB-231 cells were treated with hexane extract, incubated with Annexin VFITC/PI and then analyzed by flow cytometry (Fig. 3). These assays revealed the percentage of apoptotic and necrotic cells observed under different treatment conditions. Untreated cells showed a high percentage of viable cells $(97.0 \%)$ and a low percentage of cell death (3\%) (Fig. 3A); in contrast, cells treated with Paclitaxel demonstrated a viability of $4.9 \%$, with $7.8 \%$ of cells that were necrotic and $87.3 \%$ that were apoptotic (Fig. 3B). Moreover, the number of viable cells decreased after treatment with $94.63 \mu \mathrm{g} / \mathrm{ml}$ of hexane extract for $6,12,24$ and $48 \mathrm{~h}$, while the corresponding percentage of apoptotic cells increased in a time-dependent manner (Fig. 3C-G). These findings indicated that the cell death due to the hexane extract was primarily the result of apoptosis, resulting in $50.15 \%$ dead cells after $48 \mathrm{~h}$ of treatment. These observations were consistent with the previously detected morphological changes. Our results indicated that the hexane extract mainly activated apoptosis rather than necrosis. Necrosis is characterized by cytosolic swelling, early loss of plasmamembrane integrity and organelle breakdown (Festjens et al., 2006). Anticancer drugs, such as cisplatin or Paclitaxel reportedly induce two different pathways of cell death, necrosis and apoptosis, in different proportions (Liao and Lieu 2005; Gonzalez et al., 2001). The assays indicated that the hexane extract of $P$. edulis promoted apoptotic cell death and decreased the proliferation of MDA-MB-231 cells.

\section{Terminal dUTP nick end labeling (TUNEL)}

To evaluate DNA fragmentation, a TUNEL assay was performed in MDA-MB-231 cells treated with $94.63 \mu \mathrm{g} / \mathrm{ml}$ of $P$. edulis extract for various times $(6,12,24,48$ and $72 \mathrm{~h})$. The results revealed that cells treated with the hexane extract displayed activation of DNA fragmentation in a time-dependent manner (Fig. 4D-H), as TUNEL staining increased over the time compared with the negative control (Fig 4A). Furthermore, apoptotic cell death was observed in MDA-MB-231 cells after DNAse or Paclitaxel treatment (Fig. 4B-C, respectively). Combined with the data from the microscopy and Annexin V-FITC assays, these findings show that $P$. edulis hexane extract specifically inhibited the proliferation of human breast cancer cells, primarily by inducing apoptosis rather than necrosis, while no effect was observed in normal MCF10A cells (data not shown). 

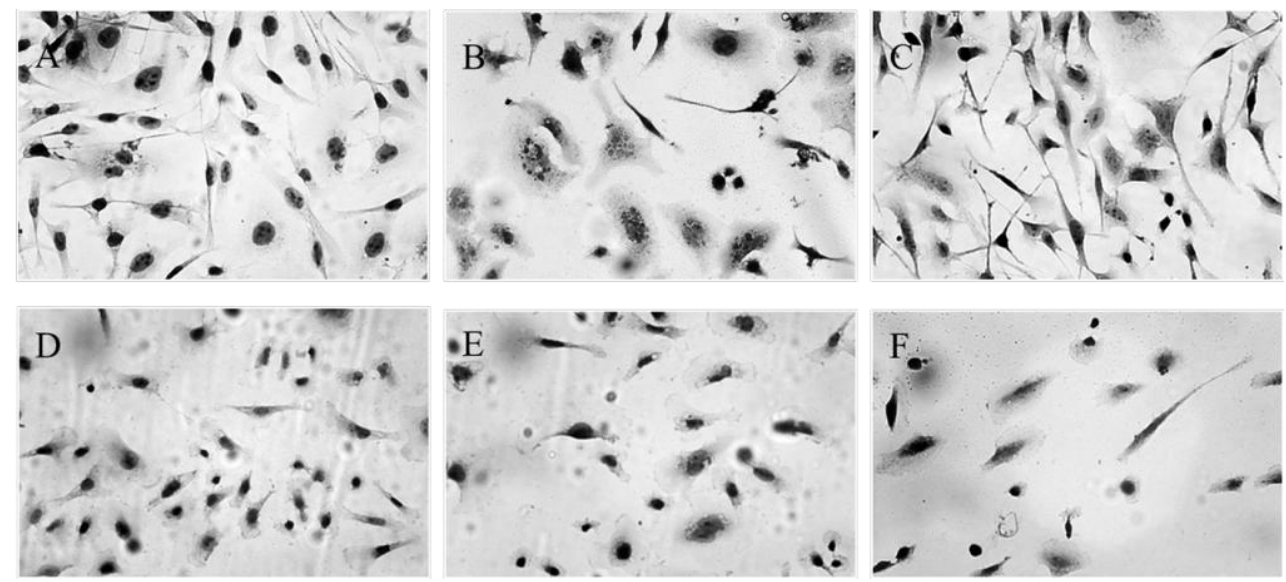

Fig. 2: Hematoxylin and eosin staining of the MDA-MB-231 cell line. A, Control cells with medium alone; B, cells treated with $0.25 \mu \mathrm{g} / \mathrm{ml}$ of Paclitaxel; C, D, $\mathrm{E}$ and $\mathrm{F}$, cells treated with $94.63 \mu \mathrm{g} / \mathrm{ml}$ hexane extract for $6,12,24$ and $48 \mathrm{~h}$, respectively (all at $40 \mathrm{x}$ magnification). Cells exposed to hexane extract showed important cellular changes that increased with the treatment period. These changes, such as size reduction, membrane blebbing and apoptotic bodies, are evident $48 \mathrm{~h}$ after treatment. These observations were consistent with the cellular viability detected by the MTT assays.
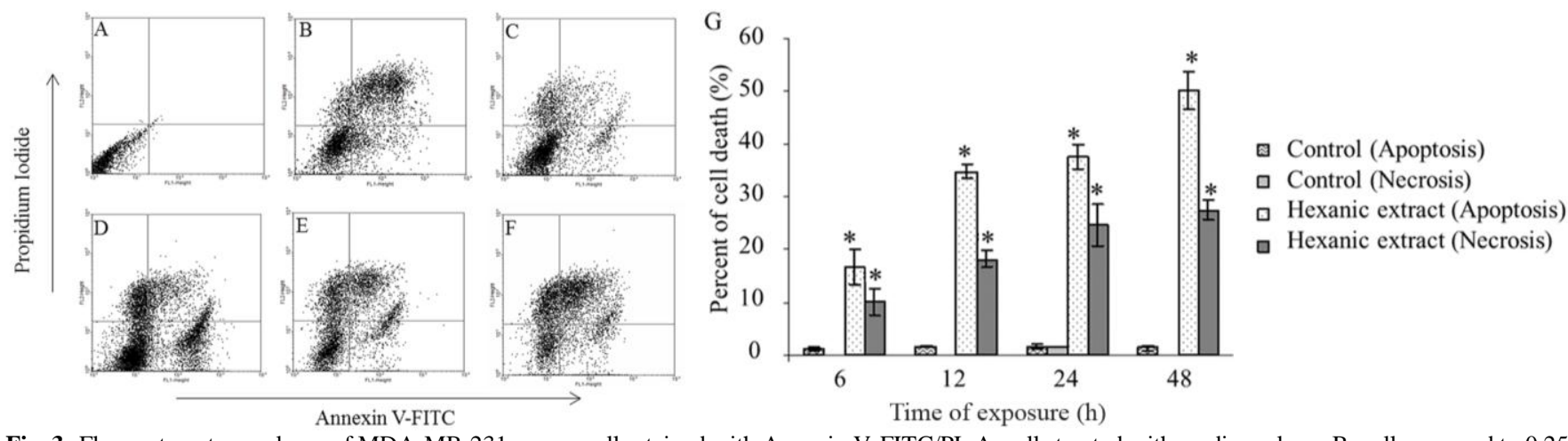

Fig. 3: Flow cytometry analyses of MDA-MB-231 cancer cells stained with Annexin V-FITC/PI. A, cells treated with medium alone; B, cells exposed to 0.25 $\mu \mathrm{g} / \mathrm{ml}$ Paclitaxel; C, D, E and F, cells treated with $94.63 \mu \mathrm{g} / \mathrm{ml}$ hexane extract for $6,12,24$ and $48 \mathrm{~h}$, respectively; G, The percentage of dead cells (apoptosis and necrosis) in the control cells and cells treated with hexane extract for differing times. The percentage of cell death is represented as the mean values + SE for at least three experiments. Significance was analyzed using a one-way ANOVA followed by Tukey's test.
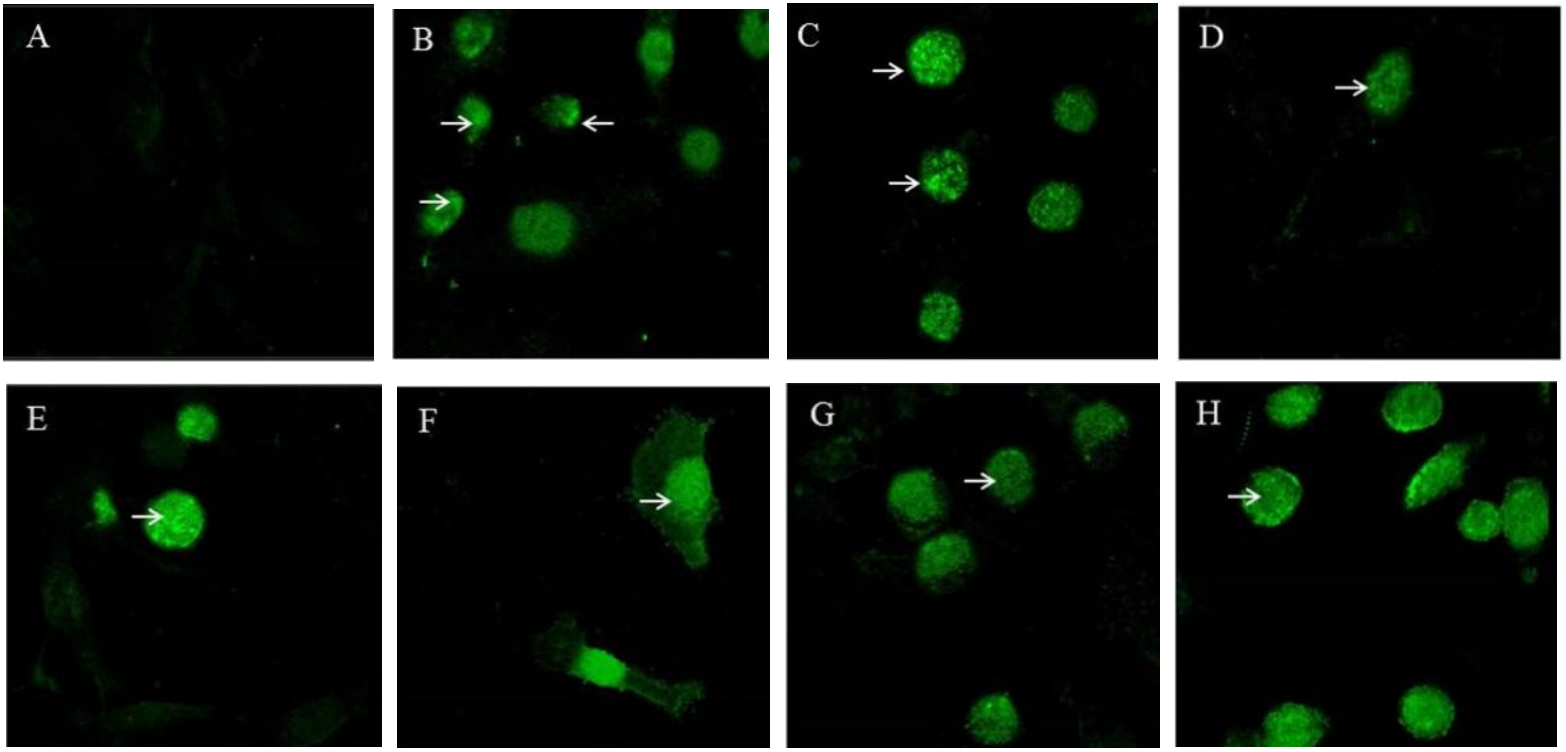

Fig. 4: TUNEL assays of the MDA-MB-231 cell line. A, Negative control cells; B, Cells treated with DNAse (3000 U/ml); C, cells treated with Paclitaxel 0.25 $\mu \mathrm{g} / \mathrm{ml}$; D, E, F and G, cells exposed to $94.63 \mu \mathrm{g} / \mathrm{ml}$ of $P$. edulis hexane extract for 6, 12, 24, 48 and $72 \mathrm{~h}$, respectively (all at $63 \mathrm{x}$ magnification). Arrows indicate the nucleus of the apoptotic cells. 


\section{Western blotting analysis}

Apoptosis can be divided into two pathways, the intrinsic and extrinsic pathways, which involve the activation of particular caspases that are constitutively expressed during the process (Kuribayashi et al., 2006). To elucidate the possible mechanism of cell death activation, a western blot analysis was performed to evaluate the protein expression of procaspase 3, 8 and 9 (Fig. 5).

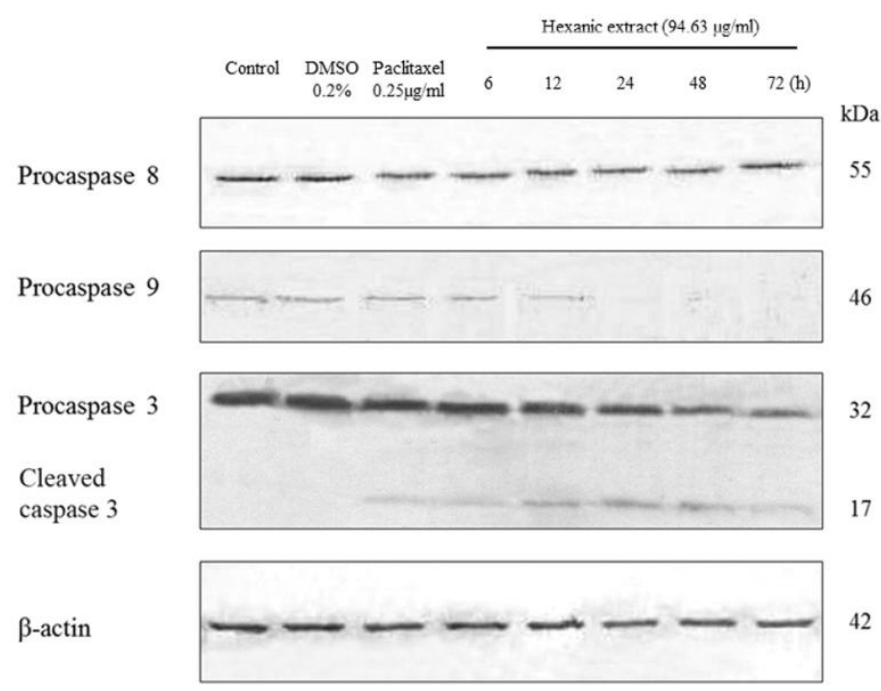

Fig. 5: Effect of P. edulis hexane extract on expression of procaspase 3,8 and 9. MDA-MB-231 breast cancer cells were exposed to the hexane extract at $94.63 \mu \mathrm{g} / \mathrm{ml}$ for $6,12,24,48$ and $72 \mathrm{~h}$.

MDA-MB-231 cells were exposed to hexane extract for different times $(6,12,24,48$ and $72 \mathrm{~h})$ prior to blotting; the results revealed that expression of procaspase $8(55 \mathrm{kDa}$ inactive protein form) did not change between the negative control cells and those exposed to hexane extract, indicating that the extrinsic apoptosis pathway had not been activated.

In contrast, the expression of procaspase $9(46 \mathrm{kDa}$ inactive protein form) decreased in cells treated with hexane extract, and was no longer detectable after $24 \mathrm{~h}$, suggesting that the protein had been activated early in treatment.

The expression of procaspase $3(32 \mathrm{kDa}$ inactive protein form) decreased, starting at $6 \mathrm{~h}$ through $72 \mathrm{~h}$ post-treatment, while the cleaved form ( $17 \mathrm{kDa}$ active form) was also detected by $6 \mathrm{~h}$ post-treatment; similar results were observed for cells exposed to Paclitaxel. These experiments indicated that the intrinsic apoptosis pathway was activated as a result of the expression and activation of caspases 3 and 9 in response to P.edulis hexane extract exposure. Caspases are proteases that serve as central components of a proteolytic system in the apoptotic process. Caspase 3 is a critical executioner of apoptosis and one of the enzymes responsible for the proteolytic activation of different proteins involved in programmed cell death (Kuribayashi et al., 2006). Additionally, the same activation pathway has been described in studies using other types of plant extracts, including those from Chrysanthemum indicum (Zong-Fang, et al., 2009), Uncaria tormentosa (De Martino et al., 2006) and Cordyceps militaris, among others (Jin et al., 2008).

\section{Phytochemical screening of $\boldsymbol{P}$. edulis hexane extract}

Preliminary phytochemical screening of different $P$. edulis extracts was then carried out to detect metabolites using standard chemical reagents (Table 1). Our results showed that $P$. edulis hexane extract is strongly cytotoxic for MDA-MB-231 breast cancer cells, an effect that may be due to the presence of various phytochemicals.

Table 1: Phytochemical screening of different $P$. edulis extracts.

\begin{tabular}{|c|c|c|c|c|}
\hline Constituents & Test & 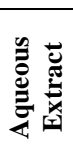 & 异 & 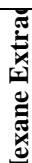 \\
\hline Sugars and Carbohydrates & Fehling's test Benedict's test & - & - & - \\
\hline Glycosides & Baljet's test Pyridine & - & - & - \\
\hline Flavonoids & Shinoda test Alkaline reagent test & - & + & - \\
\hline Tannins & Gelatin solution Ferric chloride test & - & - & - \\
\hline Coumarins & $\mathrm{KOH}$ - ethanol solution & + & + & + \\
\hline Alkaloids & $\begin{array}{l}\text { Dragendorff's reagent Wagner's } \\
\text { reagent }\end{array}$ & - & - & - \\
\hline Steroids and Terpenes & Liebermann - Buchard test & - & + & + \\
\hline Sesquiterpenes & Hydroxylamine & - & - & - \\
\hline Saponins & Foam test Rosenthaler & - & - & - \\
\hline Quinones & Borntrager test & - & + & + \\
\hline
\end{tabular}

However, traditional medicine utilizes an aqueous infusion. Thus, the differences observed in the cytotoxic activity on breast cancer cells between the hexane and aqueous extracts may be due to the extraction method performed, which enriched the concentrations of different bioactive compounds in the hexane extract, such as terpenes and quinones. The preliminary phytochemical characterization of the hexane extract from $P$. edulis showed the presence of terpenes, quinones and coumarins, which could be involved in the induction of programmed cell death in the MDA-MB-231 cells.

The identification of metabolites in the hexane extract is currently in progress and will allow us to associate the cytotoxic effect with specific chemical components. Interestingly, different types of extracts obtained from trees of the Bignoniaceae family contain similar metabolite profiles (Daniel 2006). Monoterpenes, such as geraniol and limonene, induce $80 \%$ tumor regression in murine models of breast cancer (Gould, 1997), while coumarins, such as esculetin, daphnetin and scopoletin, exert strong cytotoxic effects on HL60 and MCF-7 cell lines, inducing morphological changes and activating apoptosis (Chu et al., 2001., JimenezOrozco et al., 2011; Kim et al., 2005; Finn et al., 2002). Moreover, quinones, such as doxorubicin, mitomicyn $\mathrm{c}$ and $\beta$-lapachol, are cytotoxic to various cancer cell lines. Quinones can accept electrons and improve the intracellular production of free radicals and reactive oxygen species in the mitochondria. This action induces cellular stress and activates apoptosis (Esteves-Souza et al., 2007).

\section{CONCLUSION}

$P$. edulis, a plant used in traditional medicine in Mexico (State of Tamaulipas), showed specific antiproliferative activity 
against the breast cancer cell line MDA-MB-231, and activated apoptosis via the intrinsic pathway. Further investigation is underway to identify and characterize the precise compounds in this extract, which could provide a very promising lead for new therapeutic drug.

\section{AKNOWLEDGEMENTS}

This work was supported by the CONACYT project 114028 and by SIP (IPN) projects SIP 20101474, SIP 20113658 and SIP 20120468. We would like to thank Dr. Mario A. Rodriguez and Dra. Patricia Talamas Rohana of the Confocal Microscopy Area from the Departamento de Infectómica y Patogénesis Molecular, CINVESTAV.

\section{REFERENCES}

Alonso-Castro AJ, Villarreal ML, Salazar-Olivo LA, GomezSanchez M, Dominguez F, Garcia-Carranca A. Mexican medicinal plants used for cancer treatment: Pharmacological, phytochemical and ethnobotanical studies. Journal of Ethnopharmacology, 2011; 133: 945 972

Agus DB, et al. The Physical Sciences Oncology Centers Network. A physical sciences network characterization of non-tumorigenic and metastatic cells. Scientific Reports, 2013; 3,1449

Bailly C. Ready for a comeback of natural products in oncology. Biochemical Pharmacology, 2009. 77:1447-1457.

Balunas MJ, Kinghorn AD. Drug discovery from medicinal plants. Life Science, 2005; 78:431-41

Chu CY, Tsai YY, Wang CJ, Lin WL, Tseng TH. Induction of apoptosis by esculetin in human leukemia cells. European Journal of Pharmacology, 2001; 416(1-2):25-32.

Cragg GM, Newman DJ. Biodiversity: A continuing source of novel drug leads. Pure and Applied Chemistry, 2005; 77(1):7-24.

Cragg GM, Newman DJ. Plants as a source of anti-cancer agents. Journal of Ethnopharmacology, 2005; 100:72-79.

Daniel M, 2006. Medicinal Plants, Chemistry and Properties. Science Publishers. E.U.A.

da Rocha AB, Lopes RM, Schwartsmann G. Natural products in anticancer therapy. Current Opinion in Pharmacology, 2001; 1:364-9.

Debnath J, Muthuswamy SK, Brugge JS. Morphogenesis and oncogenesis of MCF10A mammary epithelial acini grown in threedimentional basement membrane cultures. Methods, 2003; 30:256-268.

de Martino L, Silva JL, Franceschelli S, Leone A, Pizza C, De Feo V. Proapoptotic effect of Uncaria tomentosa extracts. Journal of Ethnopharmacology, 2006; 107: 91-94. y Práctica de

de Vita V, Hellman S, Rosenberg SA. 2005. Cáncer, Principios

Oncologia. Volumen 1. $5^{\text {a }}$ Edición. Ed Médica Panamericana. Madrid, España.

Esteves-Souza A, Figueiredo DV, Esteves A, Câmara CA, Vargas MD, Pinto AC, Echevarria A. Cytotoxic and DNA-topoisomerase effects of lapachol amine derivatives and interactions with DNA. Brazilian Journal of Medical and Biological Research, 2007; 40:1399-1402.

Ferlay J, Soerjomataram I, Ervik M, Dikshit R, Eser S, Mathers C, Rebelo M, Parkin DM, Forman D, Bray F. 2013. GLOBACAN 20012 V1.0, Cancer Incidence anad Mortality Worldwide: IARC CancerBase No. 11.

Festjens N, Vanden BT, Vandenabeele P. Necrosis, a wellorchestrated form of cell demise: signalling cascades, important mediators and concomitant immune response. Biochimica et Biophysica Acta, 2006; 1757:1371-1387.

Finn GJ, Kenealy E, Creaven BS, Egan DA. In vitro cytotoxic potential and mechanism of action of selected coumarins, using human renal cell lines. Cancer Letters, 2002; 8: 183(1) 61-8.
Gonzalez VM, Fuertes MA, Alonso C, Perez JM. Is cisplatininduced cell death always produced by apoptosis? Molecular Pharmacology, 2001; 59 (4): 657-63.

Gould MN. Cancer chemoprevention and therapy by monoterpenes. Environ Health Perspect, 1997; 105 (4): 977-979.

Graham JG, Quinn ML, Fabricant DS, Farnsworth NR. Plants used against cancer, an extension of the work of Jonathan Hartwell. Journal of Ethnopharmacology, 2000; 73:347-377.

Hernandez-Galicia E, Aguilar-Contreras A, Aguilar-Santamaria L, Roman-Ramos R, Chavez-Miranda AA, García-Vega LM, Flores-Saenz JL, Alarcon-Aguilar FJ. Studies on hypoglycemic activity of mexican medicinal plants. Proceedings of the Western Pharmacology Society, 2002; 45: 118-124.

Hofman FM, Kanesberg B, Smith D, Garrison D, Sevier ED. Stability of Tand B-cell numbers in human peripheral blood. American Journal of Clinical Pathology, 1982; 77(6):710-3.

Jimenez-Orozco FA, Roman AA, Vega-Lopez A, DominguezLopez ML, Garcia-Mondragon MJ, Maldonado- Espinoza A, Lemini C, Mendoza-Patiño N, Mandoki JJ, Maldonado-Espinoza A. Differential effects of esculetin and daphnetin on in vitro cell proliferation and in vivo estrogenicity. European Journal of Pharmacology, 2001; 668(1-2):35-41.

Jin CY, Kim GY, Choi YH. Induction of apoptosis by aqueous extract of Cordyceps militaris through activation of caspases and inactivation of AKT in human breast cancer MDA-MB-231 cells. Journal of Microbiology and Biotechnology, 2008; 18(12):1997-2003.

Kim EK, Kwon KB, Shin BC, Seo EA, Lee YR, Kim JS, Park JW, Ryu DG. Scopoletin induces apoptosis in human promyeloleukemic cells, accompained by activations of nuclear factor kappaB and caspase-3. Life Science, 2005; 77(7):824-36.

Kuribayashi K, Mayes PA, El-Deiry WS. What are caspases 3 and 7 doing upstream of the mitochondria? Cancer Biol Ther, 2006; 5 , 763-765

Laza LD, Rodríguez LI, Sardiña CG. Descubrimiento y desarrollo de agentes cancerígenos derivados de plantas medicinales. Revista Cubana de Plantas Medicinales, 2003; 8:3.

Liao PC, Lieu CH. Cell cycle specific induction of apoptosis and necrosis by paclitaxel in the leukemic U937 cells. Life Sciences, 2005; 76 (14): 1623-1639.

Loyola V, Vazquéz F. 2006. Methods in Molecular Biology: Plant Cell Culture Protocols. 2a edición. Ed. Humana Press Inc. E.U.A vol. 318

Moura MD, Sousa JS, Oliveira RAG, Diniz MFF, BarbosaFilho JM. Natural products reported as potential inhibitors of uterine cervical neoplasia. Acta Farmaceutica Bonaerense, 2002; 21(1):6774

Newman DJ, Cragg GM. Natural products as sources of new drugs over the last 25 Years. Journal of Natural Products, 2007; 70, 461477.

Newman DJ. Natural Products as Leads to Potential Drugs: An Old Process or the New Hope for Drug Discovery? Journal of Medicinal Chemistry, 2008; 51:2589-2599.

Ofir R, Seidman R, Rabinski T, Krup M, Yavelsky V, Weinstein Y, Wolfson M. Taxol induced apoptosis in human SKOV3 ovarian and MCF7 breast carcinoma cells is caspase-3 and caspase- 9 independent. Cell Death Differ, 2002; 9(6):636-42.

Pennington TD, Sarukhan J. 2005. Árboles tropicales de México: Manual para la identificación de las principales especies. UNAM.

Perez RM, Perez C, Zavala MA, Perez-Gutierrez S. Actividad hipoglucemiante de Bouvardia terniflora, Brickellia veronicaefolia y Parmentiera edulis. Salud Pública de México, 1998; 40(4):354-358.

Perez RM, Perez C, Zavala MA, Perez-Gutierrez S, Hernandez $\mathrm{H}$, Lagunes F. Hypoglycemic effects of lactucin-8-O-methylacrylate of Parmentiera edulis fruit. Journal of Ethnopharmacology, 2000; 71:391394.

Rzedowsky GC, Rzedowsky J. 2001. Faneroganic Flora of Mexico Valley. $2^{\mathrm{a}}$ edition. Ecology Institute, A. C. and Nacional Comision for the knowledge and use of Biodiversity, Patzcuaro, Michoacán 
Shrivastava R, Sharma R, Mishra J, Dubey S. Preliminary Phytochemical Screening of Euphorbia thymifolia Linn. Journal of Chemical, Biological and Physical Sciences, 2013; 3(4): 2840-2844.

21.

Sorela BJ. Cuajilote (Parmentiera edulis). Tlahui-Medic, 2006;

Stander A, Marais S, Stivaktas V, Vorster C, Albrecht C, Lottering ML, Joubert AM. In vitro effects of Sutherlandia frutescens water extracts on cell numbers, morphology, cell cycle progression and cell death in a tumorigenic and a non-tumorigenic epithelial breast cell line. Journal of Ethnopharmacology, 2009; 124:45-60.

Waizel BJ. 2012. Las plantas y su uso antitumoral. Ed. Instituto Politécnico Nacional. México, D.F. Primera Edición.

Youn M, Kim J, Park S, Kim Y, Park C, Kim ES, So HS, Park R. Potential anticancer properties of the water extract of Inontus obliquus by induction of apoptosis in melanoma B16-F10 cells. Journal of Ethnopharmacology, 2009; 121: 221-228
Zong-Fang L, Zhi-Dong W, Yuan-Yuan J, Shu Z, Chen H, Jun $\mathrm{L}$, Xian-Ming X. Induction of apoptosis and cell cycle arrest in human HCC MHCC97H cells with Chrysanthemum indicum extract. World Journal of Gastroenterology, 2009; 28; 15(36): 4538-4546.

\section{How to cite this article:}

Estanislao CCG, Ordaz CP, San Martín EM, Pérez NH, Pérez GI and Gómez MCG. Cytotoxic effect and apoptotic activity of Parmentiera edulis DC. hexane extract on the breast cancer cell line MDA-MB-231. J App Pharm Sci, 2016; 6 (01): 015-022. 